\section{Comparative Effects of Radon Inhalation According to Mouse Strain and Cisplatin Dose in a Cisplatin-induced Renal Damage Model}

\author{
Kaori Sasaoka ${ }^{1}$, Takahiro Kataoka ${ }^{1}$, Norie Kanzaki ${ }^{1}$, Yusuke Kobashi ${ }^{1}$, \\ Akihiro Sakoda ${ }^{2}$, Yuu Ishimori ${ }^{2}$ and Kiyonori Yamaoka ${ }^{1, *}$ \\ ${ }^{1}$ Graduate School of Health Sciences, Okayama University, 5-1 Shikata-cho, \\ 2-chome, Kita-ku, Okayama 700-8558, Japan \\ ${ }^{2}$ Ningyo-toge Environmental Engineering Center, Japan Atomic Energy Agency, \\ 1550 Kamisaibara, Kagamino-cho, Tomata-gun, Okayama 708-0698, Japan
}

\begin{abstract}
A B S T R A C T
Cisplatin (CDDP) is widely used for treating solid cancers; however, it induces nephrotoxicity caused by oxidative stress. Here, we investigated whether radon inhalation has different effects against CDDPinduced renal injury in two mouse strains differing in radiosensitivity, and determined the appropriate dose of CDDP combined with radon inhalation for highly radiosensitive mice. CDDP was administered at $20 \mathrm{mg} / \mathrm{kg}$ weight to $\mathrm{C} 57 \mathrm{BL} / 6 \mathrm{~J}$ and $\mathrm{BALB} / \mathrm{c}$ mice after radon inhalation at $1000 \mathrm{~Bq} / \mathrm{m}^{3}$ and $2000 \mathrm{~Bq} / \mathrm{m}^{3}$ for $24 \mathrm{~h}$. Radon inhalation had a slight positive effect against CDDP toxicity in C57BL/6J mice with respect to improved hair condition, whereas radon inhalation exacerbated CDDP-induced toxicity in BALB/c mice, such as a decrease in hair condition, higher creatinine levels, and decreased antioxidant contents (catalase and glutathione). When BALB/c mice were treated with a lower dose of CDDP (15 mg/kg) after $1000 \mathrm{~Bq} / \mathrm{m}^{3}$ radon inhalation, the creatinine level was reduced and the superoxide dismutase content was increased, suggesting that this combination might have a protective effect against the CDDP-induced renal damage. The supportive effect of radon inhalation shows its good potential as a candidate treatment to alleviate CDDP-induced renal damage in veterinary medicine.
\end{abstract}

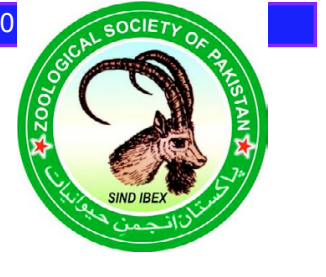
CrossMark

Article Information
Received 23 June 2017
Revised 30 July 2017
Accepted 02 October 2017
Available online 25 April 2018
Authors' Contribution
KS, TK and KY designed the study.
KS, NK, YK, TK, YI and AS collected
samples and analyzed data. KS, TK
and KY wrote the article.
Key words
Cisplatin, Oxidative stress, Renal
injury, Radon, Mice strain.

Accepted 02 October 2017

Authors' Contribution

KS, NK, YK, TK, YI and AS collected

samples and analyzed data. KS, TK

Cisplatin, Oxidative stress, Rena

injury, Radon, Mice strain.

\section{INTRODUCTION}

$\mathrm{C}$ isplatin (cis-diamminedichloroplatinum II, CDDP) is a widely used chemotherapeutic agent for various solid organ tumors such as tumors of the head, neck, testis, ovaries, and bladder (Cetin et al., 2006; Rana et al., 2016; Santos et al., 2007). CDDP is well known to be taken up by the proximal tubule cells and accumulates in the mitochondria of these cells (Hanigan and Devarajan, 2003; Noori and Mahboob, 2010; Prabhu et al., 2013; Uehara et al., 2011; Yao et al., 2007). However, CDDP has a toxic effect by covalently binding to DNA (Hato et al., 2014). Although CDDP also has ototoxicity, gastrotoxicity, and myelosuppression, the main dose-limiting toxicity of the drug rests in this nephrotoxicity. Oxidative stress has been proposed as a key contributing factor to CDDP-induced nephrotoxicity (Ozkok and Edelstein, 2014).

Oxidative stress represents an imbalance between

\footnotetext{
* Corresponding author: yamaoka@md.okayama-u.ac.jp 0030-9923/2018/0003-1157 \$ 9.00/0

Copyright 2018 Zoological Society of Pakistan
}

the production of reactive oxygen species (ROS) and their removal by antioxidant substances (Galle, 2001). ROS such as superoxide $\left(\mathrm{O}_{2}^{-}\right)$are caused by continuous oxygen consumption, and are produced within the mitochondria; antioxidant substances such as superoxide dismutase (SOD), catalase (Cat), and glutathione (GSH) eliminate these ROS (Hanigan and Devarajan, 2003; Kruidering et al., 1997). However, the uptake of CDDP in cells and their subsequent accumulation in the mitochondria induces a decrease in the activities of SOD, Cat, and GSH; moreover, intracellular GSH levels are further decreased or depleted owing to the rapid reaction with CDDP to promote its transformation to highly reactive forms (Ozkok and Edelstein, 2014; Uehara et al., 2011). This phenomenon contributes to the accumulation of ROS, leading to a state of oxidative stress within the cell (Pabla and Dong, 2008). Furthermore, CDDP has been suggested to induce mitochondrial dysfunction, and thus ROS are generated from the respiratory chains of these malfunctioning mitochondria (Kawai et al., 2006; Oh et al., 2016; Ozkok and Edelstein, 2014; Pabla and Dong, 2008).

Radon $\left({ }^{222} \mathrm{Rn}\right)$ is a natural radioactive gas that emits 
$\alpha$-rays and is absorbed in the body through the lungs via respiration as well as through the skin (Kataoka et al., 2016). Radon is delivered to many tissues through the bloodstream and throughout the body (Nishiyama et al., 2013), and is lipo-soluble with a high amount of energy release (Yamato et al., 2013). At the Misasa Medical Center of Okayama University Hospital, radon-based therapy has been performed using a concentration of 2000 $\mathrm{Bq} / \mathrm{m}^{3}$ and $42^{\circ} \mathrm{C}$ at room temperature (Sasaoka et al., 2016). Indications of this therapy are respiratory diseases such as bronchial asthma, pain-related diseases such as osteoarthritis, and digestive diseases such as chronic pancreatitis and gastroenteritis.

We previously reported that radon inhalation could enhance antioxidant function in various organs in mice, such as the brain, lung, pancreas, liver, and kidney (Kataoka et al., 2011). Moreover, radon inhalation was found to mitigate some ROS-related diseases, including the effective prevention and treatment of the renal injury related to streptozotocin-induced type 1 diabetes and of hepatic and renal injuries induced by carbon tetrachloride (Kataoka et al., 2011; Nishiyama et al., 2015). Therefore, radon inhalation might help to suppress the renal damage induced by CDDP owing to its antioxidant functions.

Chronic kidney diseases are observed with a high prevalence in geriatric dogs and cats at $0.4-1.5 \%$ and $10 \%$, respectively (Finch et al., 2016; Fiocchi et al., 2017). Thus, the widespread use of CDDP in the treatment of various solid tumors in these animals, as well as in humans, is associated with a problematic issue of nephrotoxicity (Knapp et al., 1987, 1988). In addition, there are several types of dog breeds (approximately 400) and cat breeds (over 40) (Parker, 2012; Vapalahti, 2016), which differ with respect to their risk of developing certain diseases such as cardiovascular, hepatic, kidney, and bone and joint diseases. Therefore, these strain-specific risks and effects of drug administration should be taken into consideration in veterinary practice.

In addition, various mouse strains have been used for animal experiments, such as C57BL/6J, BALB/c, ICR, and Swiss albino mice (Maliakel et al., 2008; Sung et al., 2008), and strain-specific differences with respect to radio-sensitivity have been documented: $\mathrm{C} 57 \mathrm{BL} / 6 \mathrm{~J}$ mice show relatively low sensitivity, whereas BALB/c mice show relatively high sensitivity (Onoue, 1960). However, no study has yet directly assessed the difference in this sensitivity between strains with respect to the effects of radon inhalation on the CDDP-induced renal injury. Furthermore, it is important to determine the suitable dosage of CDDP administration combined with radon inhalation in a highly radiosensitive mouse strain.

Accordingly, the aims of the present study were to evaluate whether radon inhalation has different effects on
CDDP-induced renal injury caused by oxidative stress in two different mouse strains differing in radiosensitivity, and to determine the effective dosage of CDDP when radon inhalation is used. Clarification of these points should be beneficial for the appropriate use of CDDP in small animals in research and veterinary practice.

\section{MATERIALS AND METHODS}

\section{Animals}

Eight-week-old male C57BL/6J mice, weighing 22.5-26.0 g, and 8-week-old male BALB/c mice, weighing 23.3-27.0 g, were purchased from Japan Charles River Laboratories Inc. (Yokohama, Japan) and housed in clear plastic cages with paper-chipping in a temperature (23.2 $\pm 2.4^{\circ} \mathrm{C}$ ) and light cycle (12 h of light and $12 \mathrm{~h}$ of dark)controlled room, and maintained on a standard laboratory diet with free access to water. Ethical approval for all protocols and experiments was obtained from the Animal Care and Use Committee of Okayama University.

\section{Experimental procedure}

The evaluation of clinical signs, and measurement of urine specific gravity and body weight in each mouse was conducted before radon inhalation, at the time of CDDP administration, and at $72 \mathrm{~h}$ after CDDP administration.

In Experiment $1, \mathrm{C} 57 \mathrm{BL} / 6 \mathrm{~J}$ mice and $\mathrm{BALB} / \mathrm{c}$ mice were divided into the following groups with seven mice per cage: control group, $1000 \mathrm{~Bq} / \mathrm{m}^{3}$ radon inhalation only group, $2000 \mathrm{~Bq} / \mathrm{m}^{3}$ radon inhalation only group, CDDP (20 $\mathrm{mg} / \mathrm{kg}$ ) only group (CDDP 20, sham), CDDP (20 $\mathrm{mg} / \mathrm{kg}$ ) administration after $1000 \mathrm{~Bq} / \mathrm{m}^{3}$ radon inhalation group (1000 Bq/m $\left.\mathrm{m}^{3}+\mathrm{CDDP} 20\right)$, and CDDP (20 mg/kg) administration after $2000 \mathrm{~Bq} / \mathrm{m}^{3}$ radon inhalation group (2000 Bq/m $\left.\mathrm{m}^{3}+\mathrm{CDDP} 20\right)$.

In Experiment 2, BALB/c mice were divided into the following groups with seven mice per cage: control group, CDDP (15 mg/kg) only group (CDDP 15, sham), CDDP $(15 \mathrm{mg} / \mathrm{kg})$ administration after $1000 \mathrm{~Bq} / \mathrm{m}^{3}$ radon inhalation group (1000 Bq/m $\left.\mathrm{m}^{3}+\mathrm{CDDP} 15\right)$, and CDDP (15 $\mathrm{mg} / \mathrm{kg}$ ) administration after $2000 \mathrm{~Bq} / \mathrm{m}^{3}$ radon inhalation group (2000 Bq/m $\left.\mathrm{m}^{3}+\mathrm{CDDP} 15\right)$.

After two days of acclimatization, the clinical signs were evaluated by calculating the body condition scores (BCS) for nutritional assessment according to the criteria of the World Small Animal Veterinary Association (Freeman et al., 2011): 1, easily palpable ribs and lumbar vertebrae, pelvic bones and all bones without detectable body fat and muscles; 2, easily visible ribs, lumbar vertebrae, pelvic bones, and all bones without palpable body fat and with slight loss of muscle; 3 , easily palpable ribs without palpable fat, visible top of the vertebrae, prominent pelvic bones with an obvious waist; 4, easily palpable 
ribs with slight body fat covering, and easily noticeable waist that can be viewed from above; 5, palpable ribs without excessive body fat, and an observable waist; 6, slight excessive body fat covering the ribs, discernible but prominent waist; 7, non-palpable ribs with heavy fat cover, obvious fat deposition over the lumbar area, and absent or barely visible waist; 8 , no palpable ribs due to heavy fat cover, fat deposition around the lumbar area, and an absent waist; 9, massive fat deposition over the thorax and spine, absent waist, and abdominal trunk with heavy fat deposition on the neck and limbs. Scale and hair condition scores were based on the system described by Miyagawa et al. (2013): 0, no scales, 1, a few substantial or systemic scales, 2, easily recognized scales systemically, and 3, massive scales systemically; and 0 , smooth and glossy hairs, 1, partially dried hair, 2, systemically dried hair, and 3 , densely tangled and rough hairs, respectively (Fig. 1). Urine samples were collected either by the urination at the time of the retention of mice or by the bladder pressure of the mice for measuring urine specific gravity. Body weights in all mice were also recorded at the time of evaluation, before radon inhalation and CDDP administration for the CDDP groups, and at $72 \mathrm{~h}$ after CDDP administration.

\section{Radon inhalation}

Mice were exposed to air only (sham) or radon at the specified concentration for $24 \mathrm{~h}$ using a radon exposure system as previously described (Kataoka et al., 2012). The concentration of radon in the mouse cage was supervised using a radon monitor (CMR-510, femo-TECH, Inc., OH, USA) and adjusted to $1000 \mathrm{~Bq} / \mathrm{m}^{3}$ or $2000 \mathrm{~Bq} / \mathrm{m}^{3}$.

\section{CDDP administration}

Immediately after radon inhalation, the CDDP groups were administered a single dose of CDDP (Wako Pure Chemical Industry Co. Ltd., Osaka, Japan) at either $15 \mathrm{mg}$ / $\mathrm{kg}$ body weight or $20 \mathrm{mg} / \mathrm{kg}$ body weight intraperitoneally (i.p.). The dose was determined so as to be sufficiently high to induce severe renal damage in mice (Ueki et al., 2013). After treatment, the mice were allowed to acclimate in the cages under a similar condition as described above for 72 h. Since the greatest severity of renal damage was detected at $72 \mathrm{~h}$ following CDDP i.p. injection, all mice were sacrificed by deep diethyl ether anesthesia or inhalation of carbon dioxide gas at $72 \mathrm{~h}$ after CDDP administration (Ueki et al., 2013).

\section{Biochemical assay}

Blood samples were drawn by cardiac puncture at $72 \mathrm{~h}$ after CDDP injection, and then centrifuged at $3,000 \times g$ for $5 \mathrm{~min}$ at $4^{\circ} \mathrm{C}$. Sera were kept at $-80^{\circ} \mathrm{C}$ until measurement of the serum creatinine (Cre) level (as an indicator of renal dysfunction) using the Quantichrom Creatinine Assay Kit (Funakoshi Co., Ltd., Tokyo, Japan) according to the manufacturer's recommendation.

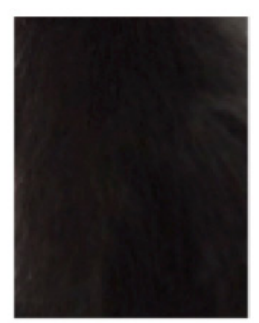

A) Hair condition and scale score of control mice

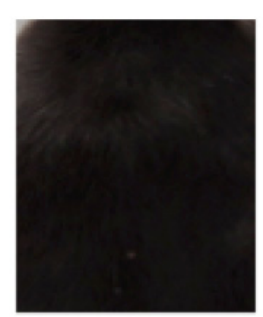

B) Score 1 of Hair condition

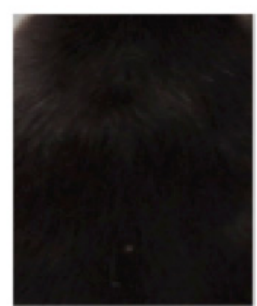

C) Score 1 of Scale score

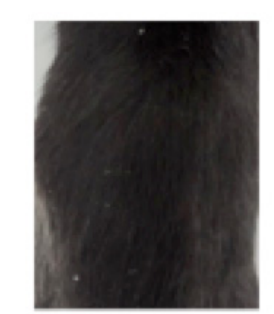

Score 2 of hair condition

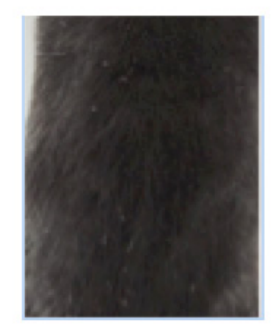

Score 2 of Scale score
Fig. 1. Representative photos of hair condition and scale score in mice. A, indicates the normal hair condition and scale score of control mice; $\mathrm{B}$, represents each score of hair condition; $\mathrm{C}$, each score of scale score.

The left and right kidneys were quickly and surgically excised, and the specimens were measured and rinsed in $10 \mathrm{mM}$ phosphate buffer solution (PBS, $\mathrm{pH}$ 7.4) and stored at $-80^{\circ} \mathrm{C}$ until analysis of the SOD and Cat activities and GSH protein levels. The left kidneys were homogenized in $10 \mathrm{mM}$ PBS ( $\mathrm{pH} \mathrm{7.4)}$ on ice, and the homogenates were centrifuged at $12,000 \times \mathrm{g}$ for $45 \mathrm{~min}$ at $4^{\circ} \mathrm{C}$. The supernatants were used for the assay of SOD activity using the nitroblue tetrazolium (NBT) reduction method with the Wako SOD test (Wako Pure Chemical Industry Co. Ltd., Osaka, Japan) according to the manufacturer instructions (Baehner et al., 1975). 

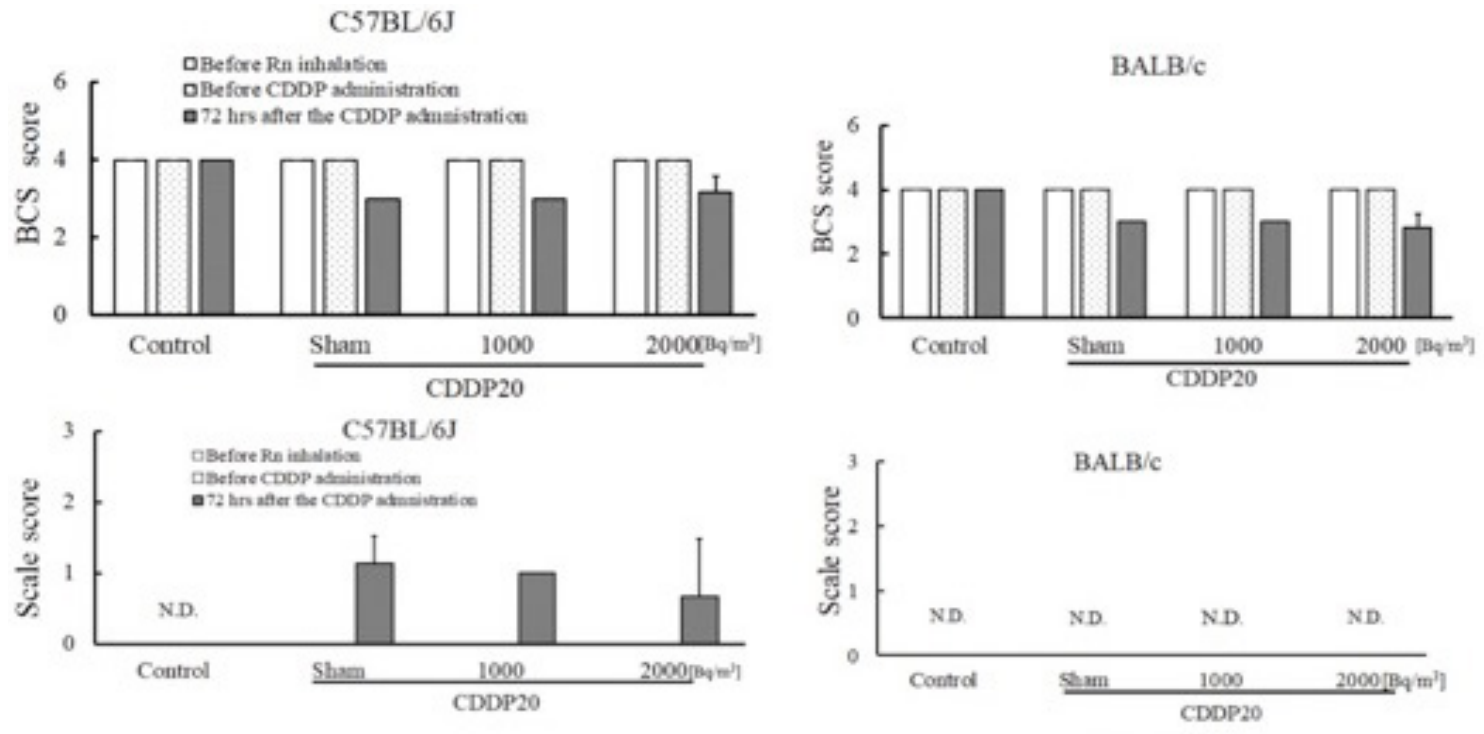

C57BL/6J

$\mathrm{BALB} / \mathrm{c}$
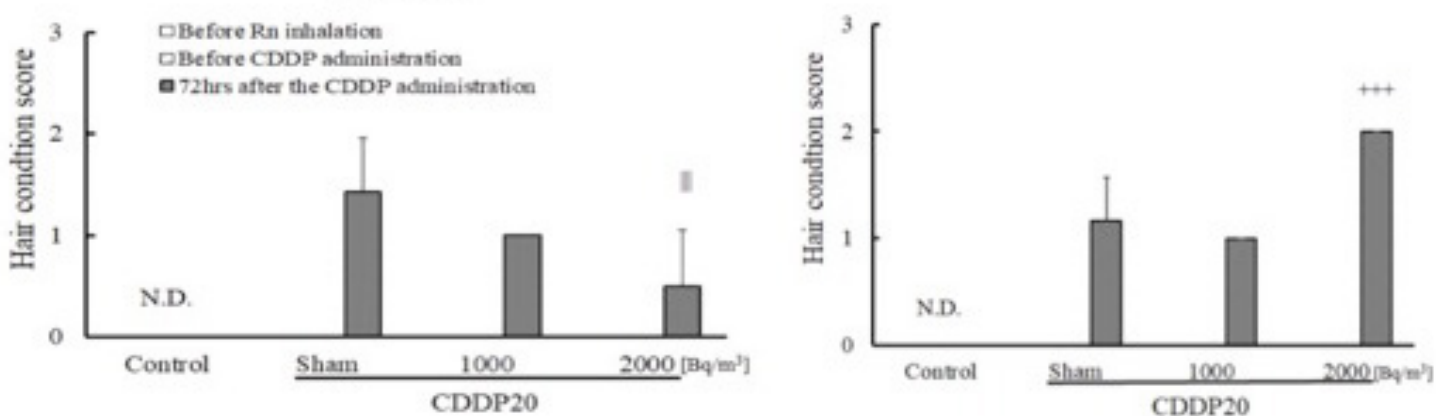

C57BL/6J strain

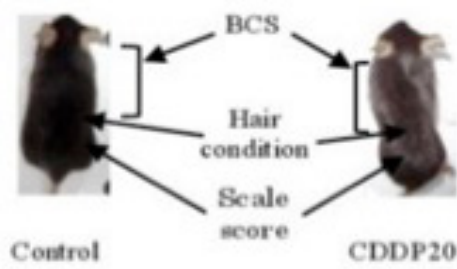

B.AL.B/c strain

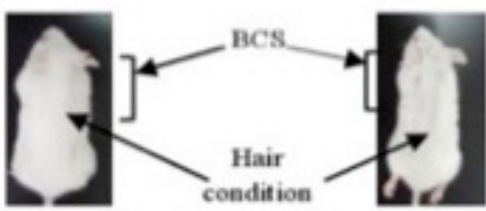

Control

CDDP20

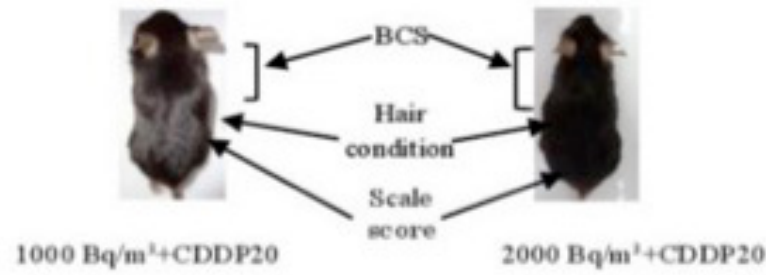

$1000 \mathrm{~Bq} / \mathrm{m}^{2}+\mathrm{CDDP} 20$

$2000 \mathrm{~Bq}^{2} \mathrm{~m}^{2}+\mathrm{CDDP}_{20}$

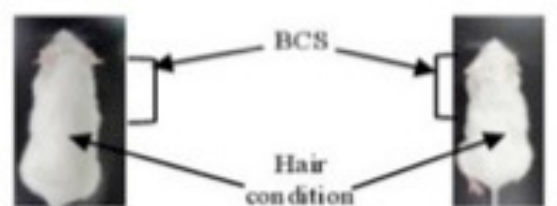

$1000 \mathrm{~Bq} / \mathrm{m}^{2}+\mathrm{CDDP}_{20}$

Fig. 2. Effects of radon inhalation on the body condition score (BCS), scale score, and hair condition score in C57BL/6J and $\mathrm{BALB} / \mathrm{c}$ mice with CDDP-induced renal injury. $\| \mid \mathrm{P}<0.001$ compares the effects of the radon inhalation group at $2000 \mathrm{~Bq} / \mathrm{m}^{3} \mathrm{vs}$. the sham group in the $\mathrm{C} 57 \mathrm{BL} / 6 \mathrm{~J}$ strain. ${ }^{++} \mathrm{P}<0.001$ indicates the comparison of the radon inhalation group at $2000 \mathrm{~Bq} / \mathrm{m}^{3} \mathrm{vs}$. the sham in the BALB/c strain. N.D. means "not detected". Photographs of mice show the methods for measuring the BCS, scale score, and hair condition score. 
In brief, inhibition of the reduction of NBT was measured at $560 \mathrm{~nm}$ using a spectrophotometer; one unit of enzyme activity was defined as $50 \%$ inhibition of NBT reduction. Cat activity was measured as the rate of hydrogen peroxide $\left(\mathrm{H}_{2} \mathrm{O}_{2}\right)$ reduction at $37^{\circ} \mathrm{C}$ detected at $240 \mathrm{~nm}$ using a spectrophotometer (Aebi et al., 1976). The assay mixture consisted of $50 \mu \mathrm{L}$ of $1 \mathrm{M}$ Tris- $\mathrm{HCl}$ buffer containing $5 \mathrm{mM}$ ethylenediaminetetraacetic acid $(\mathrm{pH}$ 7.4), $900 \mu \mathrm{L}$ of $10 \mathrm{mM} \mathrm{H}_{2} \mathrm{O}_{2}, 30 \mu \mathrm{L}$ of deionized water, and $20 \mu \mathrm{L}$ of the supernatants of the kidneys. Cat activity was calculated using a molar extinction coefficient of 7.1 $\times 10^{-3} \mathrm{M}^{-1} \mathrm{~cm}^{-1}$. The GSH content was measured using the GSSG/GSH Quantification Kit (Dojindo Molecular Technologies Inc., Kumamoto, Japan). In brief, the left kidneys were homogenized with 5\% 5-sulfosalicylic acid and centrifuged at $8,000 \times g$ for $10 \mathrm{~min}$. The supernatants were used for the assay based on the colorimetric reaction of GSH by detecting the absorption at $415 \mathrm{~nm}$. Protein concentrations were measured using the Bradford method with the protein Quantification Kit-Rapid (Dojindo Molecular Technologies Inc., Kumamoto, Japan) (Bradford, 1976).

\section{Statistical analysis}

Data are presented as the mean \pm standard error of the mean (SEM). The statistical significance of differences was determined by t-tests, Mann-Whitney's U test and Kruskal-Wallis test or post-hoc Tukey's tests or Dunnet test for multiple comparisons where appropriate. $\mathrm{P}<0.05$ was considered statistically significant.

\section{RESULTS}

\section{Clinical signs}

In Experiment 1, the BCS tended to be reduced at $72 \mathrm{~h}$ after CDDP administration in all CDDP 20 groups compared with the control group for both strains (Fig. 2). Scales were recognized in the C57BL/6J strain and the scale score tended to be reduced in the $2000 \mathrm{~Bq} / \mathrm{m}^{3}+\mathrm{CDDP}$ 20 group compared with that of the CDDP 20 group (Fig. 2). No scales were detected in the BALB/c mice (Fig. 2). Similarly, in Experiment 2 using BALB/c mice only with a lower CDDP dose (15 kg/mg), the BCS tended to be reduced at $72 \mathrm{~h}$ after CDDP administration in all groups compared with that of the control group (Fig. 3). However, there was no difference in the overall BSC between the CDDP 15 and CDDP 20 administration groups at $72 \mathrm{~h}$ after CDDP administration; no scales were observed (Fig. 3).

In the C57BL/6J strain, the hair condition score of the $2000 \mathrm{~Bq} / \mathrm{m}^{3}+\mathrm{CDDP} 20$ group was significantly reduced compared with that of the CDDP 20 group $(\mathrm{P}<0.001$; Fig. $2)$. By contrast, in the BALB/c strain, the hair condition score in the $2000 \mathrm{~Bq} / \mathrm{m}^{3}+\mathrm{CDDP} 20$ group was significantly increased compared with that of the CDDP 20 group $(\mathrm{P}<$ 0.001; Fig. 2). In addition, the hair condition score was significantly higher in the $2000 \mathrm{~Bq} / \mathrm{m}^{3}+\mathrm{CDDP} 15$ group than that of the CDDP 15 group $(\mathrm{P}<0.001$; Fig. 3$)$.
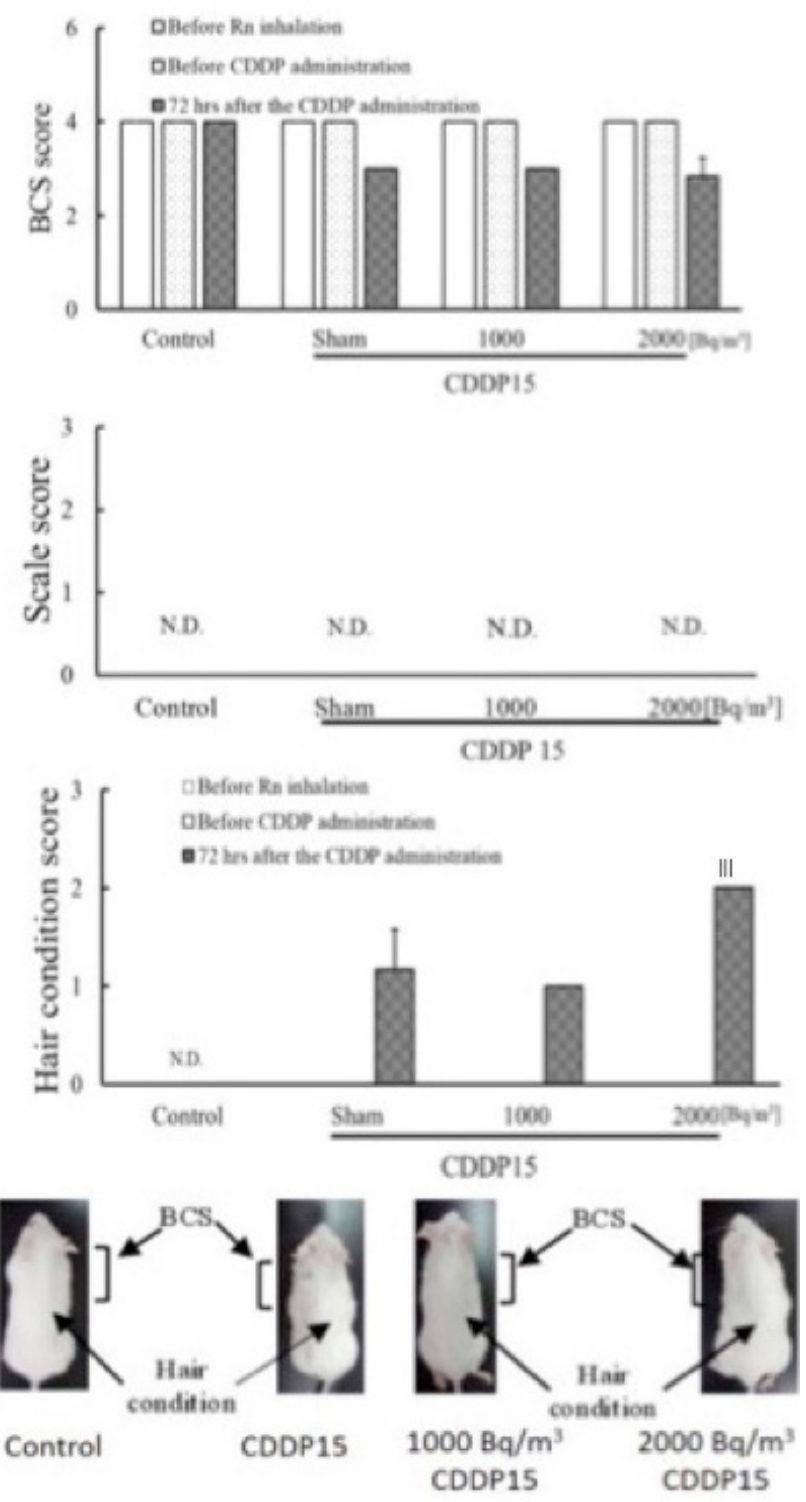

Fig. 3. Effects of radon inhalation on the body condition score (BCS) and hair condition score in BALB/c mice with $15 \mathrm{mg} / \mathrm{kg}$ CDDP-induced renal injury. ${ }^{\|} \mathrm{P}<0.001$ indicates the comparison of the group treated with $15 \mathrm{mg} / \mathrm{kg}$ CDDP after radon inhalation at $2000 \mathrm{~Bq} / \mathrm{m}^{3}$ vs. the sham. N.D. means "not detected." Pictures of mice indicate the method of measuring the BCS and hair condition score. 

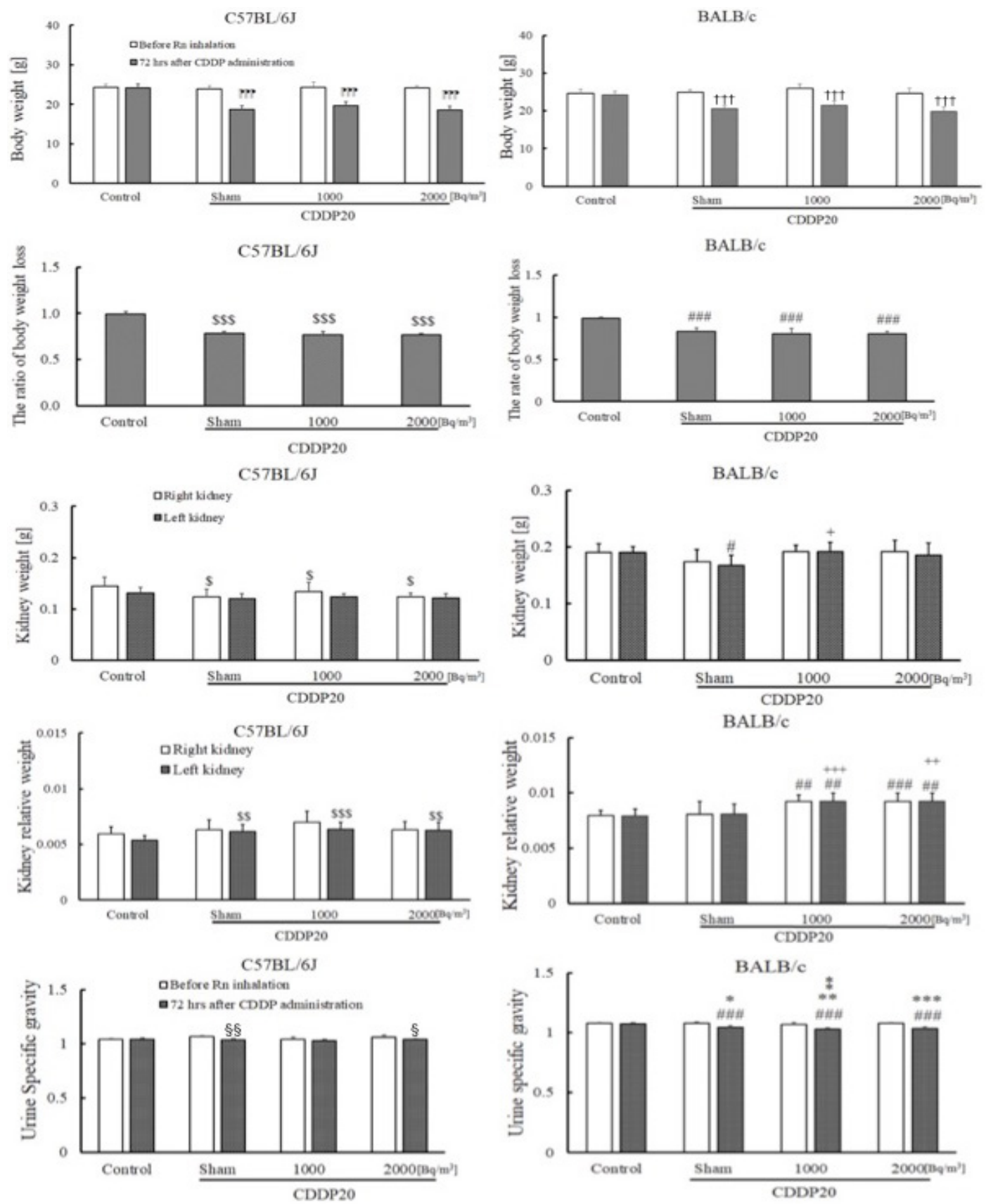

Fig. 4. Effects of radon inhalation on the influence of $20 \mathrm{mg} / \mathrm{kg}$ CDDP administration in body weight, the rate of body weight loss, absolute and relative kidney weight, and urine specific gravity in C57BL/6J and BALB/c mice with CDDP-induced renal

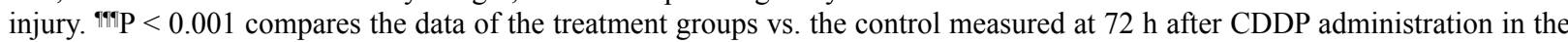
$\mathrm{C} 57 \mathrm{BL} / 6 \mathrm{~J}$ strain; the sham group received $20 \mathrm{mg} / \mathrm{kg}$ CDDP only with air inhalation. ${ }^{\dagger+\mathrm{P}}<0.001$ indicates the comparison of the treatment groups vs. the control in the BALB/c strain at $72 \mathrm{~h}$ after CDDP administration. ${ }^{\$} \mathrm{P}<0.05,{ }^{\$ \$} \mathrm{P}<0.01,{ }^{\$ \$ s} \mathrm{P}<0.001$ indicate comparisons of the treatment group vs. the control in the $\mathrm{C} 57 \mathrm{BL} / 6 \mathrm{~J}$ strain. ${ }^{\#} \mathrm{P}<0.05,{ }^{\#} \mathrm{P}<0.01,{ }^{\# \#} \mathrm{P}<0.001$ indicate the treatment groups vs. the control in the BALB/c strain. ${ }^{\S} \mathrm{P}<0.05$ and ${ }^{\S} \mathrm{P}<0.01$ compare data at $72 \mathrm{~h}$ after CDDP administration vs. before radon inhalation in the $\mathrm{C} 57 \mathrm{BL} / 6 \mathrm{~J}$ strain. $* \mathrm{P}<0.05, * * \mathrm{P}<0.01$, and $* * * \mathrm{P}<0.001$ compare the data at $72 \mathrm{~h}$ after CDDP administration in the treatment groups vs. before radon inhalation in the BALB/c strain. ${ }^{+} \mathrm{P}<0.05,{ }^{++} \mathrm{P}<0.01$, and ${ }^{++} \mathrm{P}<0.001$ indicate the CDDP and radon inhalation groups vs. the sham in the BALB/c strain. $\mathrm{P}<0.05$ indicates the $\mathrm{CDDP}$ and $1000 \mathrm{~Bq} / \mathrm{m}^{3}$ inhalation group vs. the sham in the BALB/c strain. 

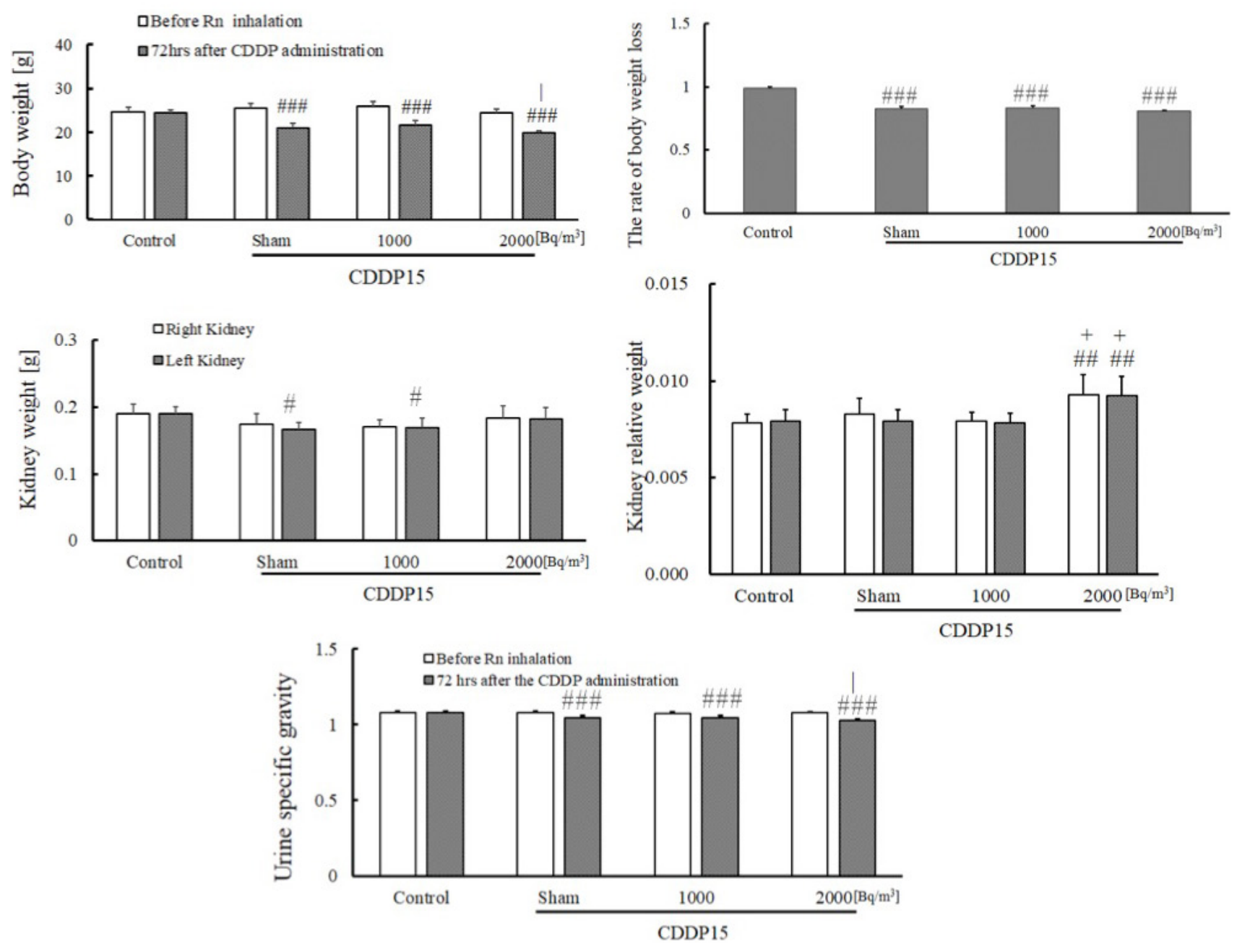

Fig. 5. Effects of radon inhalation on the $15 \mathrm{mg} / \mathrm{kg}$ CDDP-induced renal injury clinical signs, body weight, the rate of body weight loss, absolute and relative kidney weight, and urine specific gravity in $\mathrm{BALB} / \mathrm{c}$ mice. ${ }^{\#} \mathrm{P}<0.05,{ }^{\# \#} \mathrm{P}<0.01$, and ${ }^{\# \# \#} \mathrm{P}<0.001$ indicate the radon inhalation groups vs. the control. $\mathrm{P}<0.05$ indicates the data at $72 \mathrm{~h}$ after CDDP administration with $2000 \mathrm{~Bq} / \mathrm{m}^{3} \mathrm{radon}$ inhalation vs. the sham $\left(15 \mathrm{mg} / \mathrm{kg}\right.$ CDDP only with air inhalation). ${ }^{+} \mathrm{P}<0.05$ indicates CDDP administration after $2000 \mathrm{~Bq} / \mathrm{m}^{3}$ radon inhalation vs. the sham.

Body weight, body weight loss, kidney weight, and urine specific gravity

Body weight was decreased at $72 \mathrm{~h}$ after the administration of $20 \mathrm{mg} / \mathrm{kg}$ CDDP in all groups compared to the control in both strains $(\mathrm{P}<0.001$; Fig. 4). The rate of body weight loss of all groups administered CDDP was lower than that of the corresponding control group, with no difference from that of the respective sham group in both strains ( $\mathrm{P}<0.001$; Fig. 4$)$. Body weight significantly decreased in all BALB/c mice treated with $15 \mathrm{mg} / \mathrm{kg}$ $\mathrm{CDDP}$ at $72 \mathrm{~h}$ after CDDP administration compared with that of the control group ( $\mathrm{P}<0.001$; Fig. 5). In addition, the body weight of the $2000 \mathrm{~Bq} / \mathrm{m}^{3}+\mathrm{CDDP} 15$ group was significantly decreased compared with that of the CDDP 15 group $(\mathrm{P}<0.05$; Fig. 5). The rate of body weight loss of all CDDP 15-administered groups was lower than that of the control group $(\mathrm{P}<0.001$; Fig. 5).

In $\mathrm{C} 57 \mathrm{BL} / 6 \mathrm{~J}$ mice, the right kidney weight was significantly reduced for all CDDP 20-administered groups compared with the control group ( $\mathrm{P}<0.05$; Fig. 4). In BALB/c mice, the left kidney weight of the CDDP 20 group was significantly decreased compared with that of the control group $(\mathrm{P}<0.05$; Fig. 4). The left kidney weight of the $1000 \mathrm{~Bq} / \mathrm{m}^{3}+\mathrm{CDDP} 20$ group was significantly 
increased compared that of the CDDP 20 group $(\mathrm{P}<$ 0.05; Fig. 4). In C57BL/6J mice, the relative weight of the left kidney was significantly increased in all groups administered CDDP 20 compared with that of the control group (CDDP 20, $\mathrm{P}<0.01 ; 1000 \mathrm{~Bq} / \mathrm{m}^{3}+\mathrm{CDDP} 20, \mathrm{P}<$ 0.001 ; and $2000 \mathrm{~Bq} / \mathrm{m}^{3}+\mathrm{CDDP} 20, \mathrm{P}<0.01$; Fig. 4). In $\mathrm{BALB} / \mathrm{c}$ mice, the relative weights of both kidneys in the $1000 \mathrm{~Bq} / \mathrm{m}^{3}+\mathrm{CDDP} 20$ and $2000 \mathrm{~Bq} / \mathrm{m}^{3}+\mathrm{CDDP} 20$ groups were significantly increased compared with those of the control group (left and right kidneys $1000 \mathrm{~Bq} / \mathrm{m}^{3}+\mathrm{CDDP}$ $20, \mathrm{P}<0.01$; right kidney $2000 \mathrm{~Bq} / \mathrm{m}^{3}+\mathrm{CDDP} 20, \mathrm{P}<$ 0.001; and left kidney $2000 \mathrm{~Bq} / \mathrm{m}^{3}+\mathrm{CDDP} 20, \mathrm{P}<0.01$; Fig. 4). The relative weights of the left kidneys of the 1000 $\mathrm{Bq} / \mathrm{m}^{3}+\mathrm{CDDP} 20$ and $2000 \mathrm{~Bq} / \mathrm{m}^{3}+\mathrm{CDDP} 20$ groups were also significantly higher than that of the CDDP 20 group (1000 Bq/m $\mathrm{m}^{3}+\mathrm{CDDP} 20, \mathrm{P}<0.001 ; 2000 \mathrm{~Bq} / \mathrm{m}^{3}+\mathrm{CDDP}$ 20, $\mathrm{P}<0.01$; Fig. 4). As shown in Figure 5, kidney weight was also significantly reduced in the left kidneys of the CDDP 15 and $1000 \mathrm{~Bq} / \mathrm{m}^{3}+\mathrm{CDDP} 15$ groups compared with that of the control group (both $\mathrm{P}<0.05$ ). Moreover, the absolute and relative weights of both kidneys in the $2000 \mathrm{~Bq} / \mathrm{m}^{3}+\mathrm{CDDP} 15$ group were increased compared with those of the CDDP 15 group $(\mathrm{P}<0.05$; Fig. 5) and control group $(\mathrm{P}<0.01$; Fig. 5$)$.

The urine specific gravities of the CDDP 20 and 2000 $\mathrm{Bq} / \mathrm{m}^{3}+\mathrm{CDDP} 20$ groups were significantly lower than that measured before radon inhalation in $\mathrm{C} 57 \mathrm{BL} / 6 \mathrm{~J}$ mice $(\mathrm{P}<$ 0.01 and $\mathrm{P}<0.05$, respectively; Fig. 4). In BALB/c mice, the urine specific gravities of all groups administered $\mathrm{CDDP}$ at $20 \mathrm{mg} / \mathrm{kg}$ were significantly decreased compared with that of the control group $(\mathrm{P}<0.001$; Fig. 4$)$, and were significantly lower at $72 \mathrm{~h}$ after CDDP administration than that measured before radon inhalation (CDDP 20, P $<0.05 ; 1000 \mathrm{~Bq} / \mathrm{m}^{3}+\mathrm{CDDP} 20, \mathrm{P}<0.01$; and $2000 \mathrm{~Bq} /$ $\mathrm{m}^{3}, \mathrm{P}<0.001$; Fig. 4). The urine specific gravity of the $1000 \mathrm{~Bq} / \mathrm{m}^{3}+\mathrm{CDDP} 20$ group was significantly decreased compared to that of the CDDP 20 group at $72 \mathrm{~h}$ after CDDP administration $(\mathrm{P}<0.05$; Fig. 4). Urine specific gravities of all groups treated with CDDP 15 were lower than that of the control group ( $\mathrm{P}<0.001$; Fig. 5), and the urine specific gravity of the $2000 \mathrm{~Bq} / \mathrm{m}^{3}+\mathrm{CDDP} 15$ group was also significantly lower than that of the CDDP 15 group ( $\mathrm{P}$ $<0.05$; Fig. 5).

\section{Index of renal injury}

To estimate the ability of radon inhalation to mitigate the renal injury induced by CDDP, Cre levels were determined as an index of renal injury. In C57BL/6J mice, there were no significant differences in Cre levels among any of the CDDP-treated mice. In BALB/c mice, the Cre levels of all CDDP-administered groups were significantly higher than that of control mice (CDDP $20 \mathrm{P}<0.05 ; 1000$ $\mathrm{Bq} / \mathrm{m}^{3}+\mathrm{CDDP} 20, \mathrm{P}<0.05$, and $2000 \mathrm{~Bq} / \mathrm{m}^{3}, \mathrm{P}<0.01$; Fig.
6A), with no difference among the three CDDP-treated groups (Fig. 6A). The Cre levels of the CDDP 15 and 2000 $\mathrm{Bq} / \mathrm{m}^{3}+\mathrm{CDDP} 15$ groups tended to be increased compared with those of the controls (Fig. 7A). However, there was a decrease in Cre of approximately $70 \%$ in the $1000 \mathrm{~Bq} /$ $\mathrm{m}^{3}+\mathrm{CDDP} 15$ group compared with that of the CDDP 15 group (Fig. 7A).

\section{Effect of radon inhalation on renal antioxidant-related substances}

To assess the antioxidative effect of radon inhalation against CDDP-induced renal injury, the antioxidant-related substances SOD, Cat, and GSH were analyzed.

The SOD activity of the CDDP 20 group was significantly decreased compared with that of the control group in $\mathrm{C} 57 \mathrm{BL} / 6 \mathrm{~J}$ mice $(\mathrm{P}<0.05$; Fig. $6 \mathrm{~B})$. In BALB/c mice, the SOD activity of the $2000 \mathrm{~Bq} / \mathrm{m}^{3}+\mathrm{CDDP} 20$ group was significantly lower than that of the control group $(\mathrm{P}<$ 0.01; Fig. 6B), whereas the SOD activity of the $1000 \mathrm{~Bq} /$ $\mathrm{m}^{3}+\mathrm{CDDP} 20$ group was significantly increased compared with that of the CDDP 20 group ( $<0.001$; Fig. 6B). Similarly, the SOD activity of the $2000 \mathrm{~Bq} / \mathrm{m}^{3}+$ CDDP 15 group was significantly decreased compared with that of the control mice $(\mathrm{P}<0.01$; Fig. 7B), whereas the activities of both the $1000 \mathrm{~Bq} / \mathrm{m}^{3}+\mathrm{CDDP} 15$ and $2000 \mathrm{~Bq} / \mathrm{m}^{3}+\mathrm{CDDP}$ 15 groups were significantly increased compared with that of the CDDP 15 group (both $\mathrm{P}<0.05$; Fig. 7B).

The Cat activities of all CDDP administration groups were significantly lower than that of control mice $(\mathrm{P}<$ 0.005 ; Fig. 6B), and there were no significant differences among the CDDP administration groups in $\mathrm{C} 57 \mathrm{BL} / 6 \mathrm{~J}$ mice. However, in $\mathrm{BALB} / \mathrm{c}$ mice, Cat activities were significantly decreased in the $1000 \mathrm{~Bq} / \mathrm{m}^{3}+\mathrm{CDDP} 20$ and $2000 \mathrm{~Bq} / \mathrm{m}^{3}+\mathrm{CDDP} 20$ groups compared with that of the control group $(\mathrm{P}<0.05$ and $\mathrm{P}<0.01$, respectively) (Fig. 6B) and CDDP 20 group $(\mathrm{P}<0.05$ and $\mathrm{P}<0.001$, respectively) (Fig. 6B). Similarly, the Cat activity of the $2000 \mathrm{~Bq} / \mathrm{m}^{3}+$ CDDP 15 group was significantly lower than that of the control group ( $\mathrm{P}<0.01$; Fig. 7B) and CDDP 15 group $(\mathrm{P}<0.001)$ (Fig. 7B).

In C57BL/6J mice, the GSH activity of the $2000 \mathrm{~Bq} /$ $\mathrm{m}^{3}+\mathrm{CDDP} 20$ group was $30 \%$ higher than that of the CDDP 20 group. However, in BALB/c mice, the GSH activities were significantly decreased in all CDDP-administered groups compared with that of the control group $(\mathrm{P}<0.01$; Fig. 6B), and the $2000 \mathrm{~Bq} / \mathrm{m}^{3}+\mathrm{CDDP} 20$ group showed a $26 \%$ decrease in GSH activity compared with that of the CDDP 20 group (Fig. 6B). In addition, the GSH activity of the $2000 \mathrm{~Bq} / \mathrm{m}^{3}+\mathrm{CDDP} 15$ group showed a $52 \%$ decrease compared with that of CDDP15 group (Fig. 7B). 

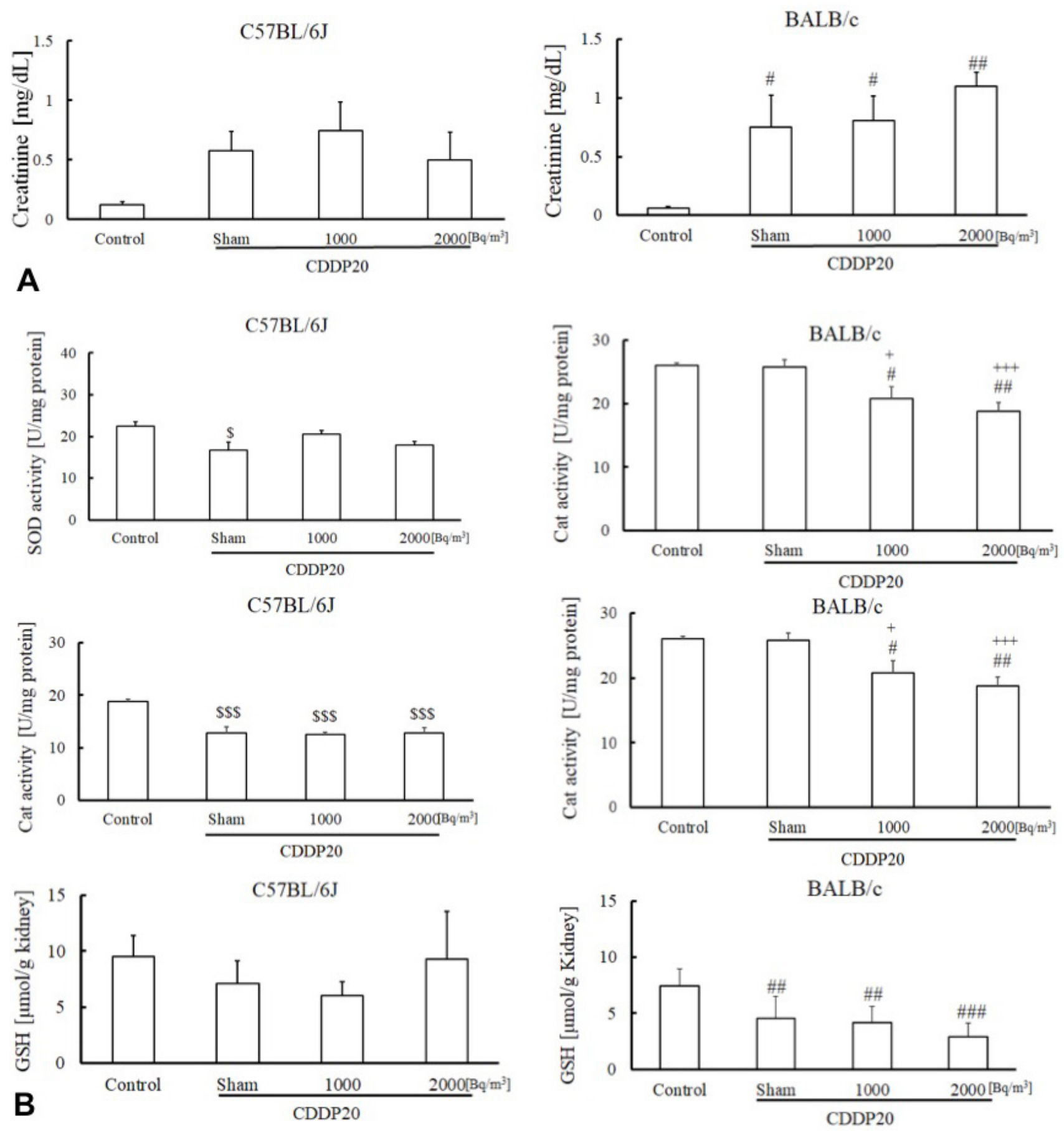

Fig. 6. Effects of radon inhalation on the influence of $20 \mathrm{mg} / \mathrm{kg}$ CDDP administration on A) the serum creatinine level, and B) antioxidant-related substances in C57BL/6J and BALB/c mice with CDDP-induced renal injury. ${ }^{\$} \mathrm{P}<0.05$ and ${ }^{\$ \$ \$} \mathrm{P}<0.001$ indicate the treatment groups vs. the control in the $\mathrm{C} 57 \mathrm{BL} / 6 \mathrm{~J}$ strain. The sham group represents the group administered with 20 $\mathrm{mg} / \mathrm{kg}$ CDDP only with air inhalation. ${ }^{\#} \mathrm{P}<0.05,{ }^{\#} \mathrm{P}<0.01$, and ${ }^{\# \#} \mathrm{P}<0.001$ indicate the treatment groups vs. the control in the BALB/c strain. ${ }^{+} \mathrm{P}<0.05$ and ${ }^{+++} \mathrm{P}<0.001$ indicate the radon inhalation groups vs. the sham in the BALB/c strain. 

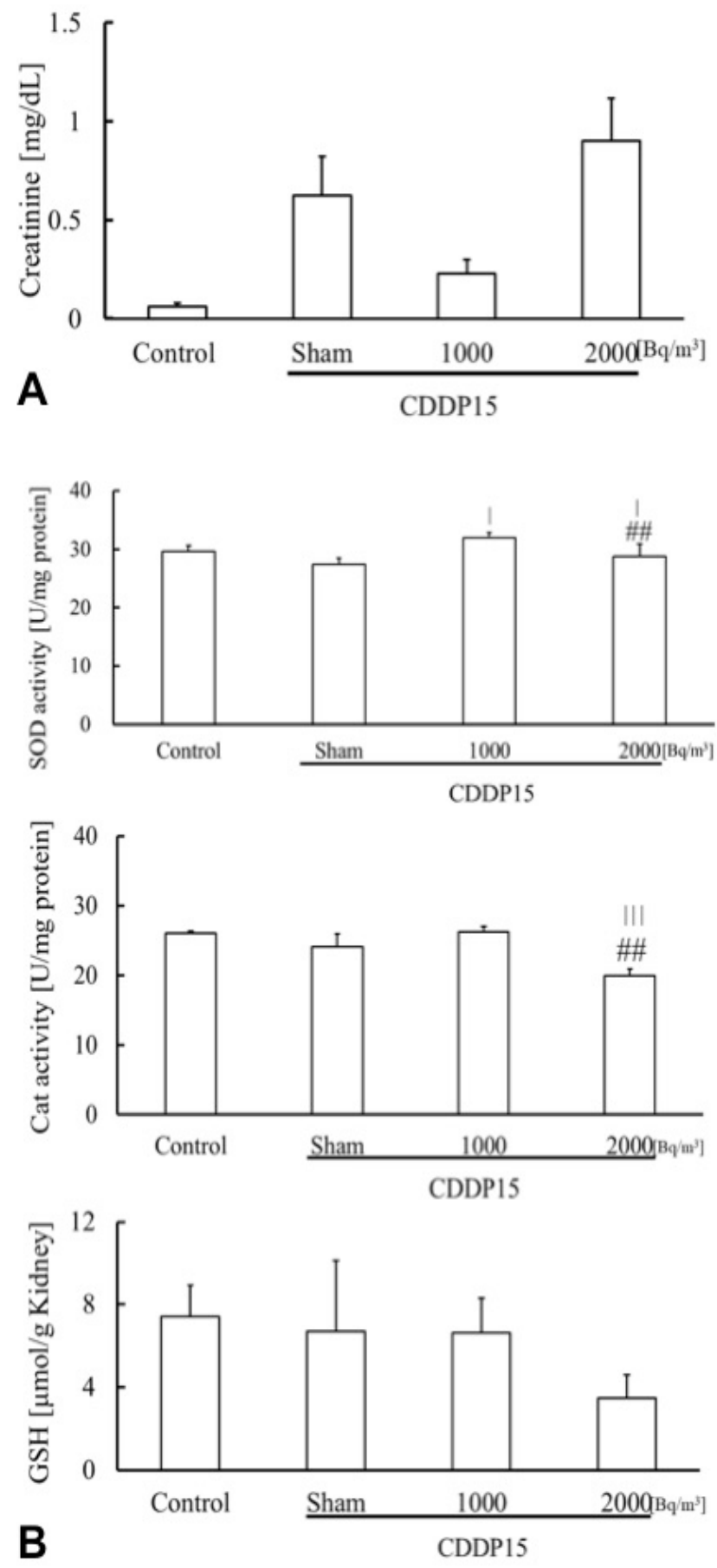

Fig. 7. Effects of radon inhalation on the changes in A) serum creatinine level and B) antioxidant-related substances caused by $15 \mathrm{mg} / \mathrm{kg}$ CDDP in BALB/c mice with CDDP-induced renal injury. ${ }^{\# P} \mathrm{P}<0.01$ indicates the treatment groups vs. the control. The sham group was treated with $15 \mathrm{mg} / \mathrm{kg}$ CDDP only with air inhalation. $\mathrm{P}<$ 0.05 and $\| \mathrm{P}<0.001$ indicate the radon inhalation groups vs. the sham.

\section{DISCUSSION}

Radon inhalation has been suggested to enhance the antioxidant functions of various organs such as the brain, lung, heart, liver, and kidney (Kataoka et al., 2011), and ROS-related diseases of these organs have been shown to be inhibited via the suppression of ROS activity. Furthermore, radon inhalation was found to effectively improve clinical signs in a study with a renal kidney failure animal model (Kataoka et al., 2012). Although CDDP is an effective chemotherapeutic agent, various side effects have been confirmed, including nephrotoxicity as a major adverse effect. The overarching aim of the present study was to evaluate the different effects of radon inhalation on mediating this CDDP-induced renal damage in two different radiosensitivity mouse strains and to determine an appropriate CDDP dose in combination with radon inhalation in the highly radiosensitive mouse strain.

Our results revealed no notable differences between strains with respect to $\mathrm{BCS}$, body weight, and the rate of body weight loss upon $20 \mathrm{mg} / \mathrm{kg}$ CDDP administration with or without radon inhalation at two concentrations. Body weight loss is a common outcome of cancer therapy, and therefore nutrition management is an important consideration (Nakahara et al., 2012). Accordingly, both body weight loss and the rate of this loss are important factors for accurately assessing the effect of CDDP. Body weight loss arises from the gastrointestinal toxicity in response to CDDP treatment, and the consequent reduction of food intake leads to a poor nutritional status (Noori and Mahboob, 2010; Rana et al., 2016). The BCS reflects the nutritious condition of animals (Freeman et al., 2011). Therefore, it is considered that the poor nutrition condition observed in $\mathrm{C} 57 \mathrm{BL} / 6 \mathrm{~J}$ and $\mathrm{BALB} / \mathrm{c}$ mice was caused by the gastrointestinal toxicity from $20 \mathrm{mg} / \mathrm{kg}$ CDDP administration. However, radon inhalation could not protect against this gastrointestinal toxicity. With respect to dose, gastrointestinal toxicity was detected with the administration of both $15 \mathrm{mg} / \mathrm{kg}$ and $20 \mathrm{mg} / \mathrm{kg}$ CDDP in combination with radon inhalation at $2000 \mathrm{~Bq} / \mathrm{m}^{3}$ given the reductions in the $\mathrm{BCS}$, body weight, and rate of body weight loss, indicating that even a relatively high radon concentration $\left(2000 \mathrm{~Bq} / \mathrm{m}^{3}\right)$ cannot suppress the reduction of food intake due to the gastrointestinal toxicity induced by CDDP administration at both doses evaluated in this study.

Poor hair quality with an increase of scales is commonly observed in animals suffering from renal injury (Canon, 2016). Therefore, we also evaluated the hair condition as well as scale scores as clinical signs of renal injury induced by CDDP to evaluate the effects of radon inhalation. The results showed that both the hair condition and scale scores were improved in mice administered with $20 \mathrm{mg} / \mathrm{kg}$ CDDP after $2000 \mathrm{~Bq} / \mathrm{m}^{3}$ radon inhalation in the 
$\mathrm{C} 57 \mathrm{BL} / 6 \mathrm{~J}$ strain, suggesting that this radon concentration may mitigate the CDDP-induced renal injury in this strain. By contrast, the hair condition further deteriorated in $\mathrm{BALB} / \mathrm{c}$ mice that received $20 \mathrm{mg} / \mathrm{kg}$ CDDP after 2000 $\mathrm{Bq} / \mathrm{m}^{3}$ radon inhalation, suggesting that a relatively high radon concentration may exacerbate the CDDP-induced renal damage, which is a mark of the high radiosensitivity of this strain. This same effect was noted with $15 \mathrm{mg} /$ $\mathrm{kg}$ CDDP administration, indicating that the extent of renal damage induced by CDDP administration may be aggravated by the combination with a high radon concentration regardless of the CDDP dose.

CDDP-treated animals also show polyuria, indicating a reduction in the urine specific gravity because of a deficiency of urine concentration (Ecelbarger et al., 2001; Nematbakhsh et al., 2013). Polyuria was confirmed following $20 \mathrm{mg} / \mathrm{kg}$ CDDP administration after inhaling $2000 \mathrm{~Bq} / \mathrm{m}^{3}$ radon in $\mathrm{C} 57 \mathrm{BL} / 6 \mathrm{~J}$ mice, and all $\mathrm{BALB} / \mathrm{c}$ mice administered either $20 \mathrm{mg} / \mathrm{kg}$ or $15 \mathrm{mg} / \mathrm{kg}$ CDDP after radon inhalation showed significant reductions of urine specific gravity, indicating that radon inhalation does not mitigate the renal damage induced by CDDP. Specifically, there was a significant reduction of urine specific gravity with $15 \mathrm{mg} / \mathrm{kg}$ CDDP administration after $2000 \mathrm{~Bq} / \mathrm{m}^{3}$ radon inhalation and with $20 \mathrm{mg} / \mathrm{kg}$ CDDP after both $1000 \mathrm{~Bq} / \mathrm{m}^{3}$ and $2000 \mathrm{~Bq} / \mathrm{m}^{3}$ radon inhalation. These findings suggest that the combination of $15 \mathrm{mg} / \mathrm{kg}$ CDDP administration and $2000 \mathrm{~Bq} / \mathrm{m}^{3}$ radon inhalation and the combination of $20 \mathrm{mg} / \mathrm{kg}$ CDDP administration and $1000 \mathrm{~Bq} / \mathrm{m}^{3}$ and $2000 \mathrm{~Bq} / \mathrm{m}^{3}$ radon inhalation does not provoke the polyuria in CDDP-induced renal damage.

The severity of renal damage can be indicated by a larger kidney weight (Nematbakhsh et al., 2013; Tokunaga et al., 1996). This enlargement of the kidney is not due to a relative effect linked to overall weight loss but rather results from edema caused by necrosis in the tubular cells (Rana et al., 2016). Therefore, both the absolute and relative kidney weights should be considered for assessments of the ability of radon inhalation to improve the CDDP-induced renal injury. The present study showed that absolute and relative kidney weights increased in the C57BL/6J mice administered $20 \mathrm{mg} / \mathrm{kg}$ CDDP after radon inhalation, indicating that the edema of the tubular cells in these kidneys was indeed induced by CDDP and could not be mitigated by radon inhalation. Similarly, the BALB/c mice showed significant increases in both the absolute and relative kidney weights with 20 $\mathrm{mg} / \mathrm{kg}$ CDDP administration after radon inhalation at both concentrations, suggesting that radon inhalation might actually worsen the necrosis of tubular cells in the kidneys in this strain. The kidney is considered to be a relatively weakly radiosensitive organ based on the different radiosensitivities in various tissues and organs. Furthermore, radon is a highly lipo-soluble substance (Yamato et al., 2013); therefore, it would be expected that radon inhalation would have minimal effects on renal injury in these strains since the kidney has less fat than the other organs. The kidney weights of BALB/c mice also increased with the combination of $15 \mathrm{mg} / \mathrm{kg}$ CDDP and $2000 \mathrm{~Bq} / \mathrm{m}^{3}$ radon, as well as $20 \mathrm{mg} / \mathrm{kg}$ CDDP and both $1000 \mathrm{~Bq} / \mathrm{m}^{3}$ and $2000 \mathrm{~Bq} / \mathrm{m}^{3}$ radon inhalation, suggesting that these combinations could further exacerbate the CDDP-induced renal injury.

Cre is filtered out of the body by the kidneys, and the level of Cre increases when the filtration function of the kidney is damaged (Prabhu et al., 2013). Likewise, the serum Cre level is elevated with increasing histological damage to the tubular cells (Palipoch and Punsawasd 2013). We did not detect an effect of radon inhalation at either concentration on the Cre level in C57BL/6J mice, indicating that radon inhalation cannot inhibit the effects of CDDP on renal damage in this strain due to its low radiosensitivity. However, in the BALB/c strain, the Cre levels actually increased with $20 \mathrm{mg} / \mathrm{kg}$ CDDP after radon inhalation at both concentrations, suggesting that the high radiosensitivity of this strain resulted in exacerbation of the CDDP-induced renal damage by radon inhalation in radon inhalation. Evaluation of the influence of CDDP dose showed that $1000 \mathrm{~Bq} / \mathrm{m}^{3}$ radon inhalation reduced the Cre level with administration of $15 \mathrm{mg} / \mathrm{kg}$ CDDP, but not significantly, indicating that radon inhalation may increase the glomerular filtration rate so that the renal injury is mitigated by a relatively low radon concentration (1000 $\left.\mathrm{Bq} / \mathrm{m}^{3}\right)$.

Given this decrease in the Cre level, we further examined antioxidant activity in the C57BL/6J and $\mathrm{BALB} / \mathrm{c}$ strains and at different CDDP administration doses in the BALB/c strain. SOD converts $\mathrm{O}_{2}^{-}$to hydrogen peroxidase $\left(\mathrm{H}_{2} \mathrm{O}_{2}\right)$, whereas Cat and $\mathrm{GSH}$ transform $\mathrm{H}_{2} \mathrm{O}_{2}$ to water $\left(\mathrm{H}_{2} \mathrm{O}\right)$ and then to oxygen $\left(\mathrm{O}_{2}\right)$ (Sasaoka et al., 2016). In addition, $\mathrm{O}_{2}^{-}$is generated by consuming oxygen in the mitochondria (Kruidering et al., 1997); indeed, $\mathrm{O}_{2}^{-}$is mainly generated from the respiratory chain in the mitochondria (Kruidering et al., 1997; Pabla and Dong, 2008). It has also been suggested that CDDP decreases the activity of antioxidants after accumulating in the mitochondria (Noori and Mahboob, 2010). In the present study, the GSH content tended to increase in the C57BL/6J strain after $2000 \mathrm{~Bq} / \mathrm{m}^{3}$ radon inhalation. This suggests that GSH plays an important role for the mitigation of the CDDP-induced renal injury in C57BL/6J mice. However, since this difference was not statistically significant, the effect of radon inhalation in this strain may be small. By contrast, in the BALB/c strain, although the SOD activity 
showed an increase in the GSH level following $1000 \mathrm{~Bq} /$ $\mathrm{m}^{3}$ radon inhalation, it was reduced following $2000 \mathrm{~Bq} /$ $\mathrm{m}^{3}$ radon inhalation with $20 \mathrm{mg} / \mathrm{kg}$ CDDP administration. The radon concentration employed in this study was determined according to the reference of the radon therapy used at Misasa Medical Center, Okayama University, and based on our previous study examining the change in SOD activity in the kidneys of BALB/c mice (Kataoka et al., 2011). In this previous study, the SOD activity in the kidney sharply increased at $24 \mathrm{~h}$, decreased at $72 \mathrm{~h}$, and then gradually increased with $1000 \mathrm{~Bq} / \mathrm{m}^{3}$ radon inhalation. However, the SOD activity did not increase at $24 \mathrm{~h}$ and remained constant with $2000 \mathrm{~Bq} / \mathrm{m}^{3}$ radon inhalation. Therefore, the low SOD activity observed with $2000 \mathrm{~Bq} / \mathrm{m}^{3}$ radon inhalation in the present study likely reflects these dynamics. Consequently, the inhalation of $2000 \mathrm{~Bq} / \mathrm{m}^{3}$ radon may not contribute to the mitigation of CDDP-induced renal injury in this strain. In addition, Cat activity and the GSH contents were significantly reduced following $1000 \mathrm{~Bq} / \mathrm{m}^{3}$ and $2000 \mathrm{~Bq} / \mathrm{m}^{3}$ radon inhalation. As mentioned above, antioxidant activity was enhanced at about $24 \mathrm{~h}$ and the effect was reduced by radon inhalation at $72 \mathrm{~h}$ (Kataoka et al., 2011). Therefore, these reductions of Cat activity and GSH content with $20 \mathrm{mg} / \mathrm{kg}$ CDDP administration might be due to this sequential change in these antioxidants. Moreover, our results showed that SOD activity was significantly high with the combination of $15 \mathrm{mg} / \mathrm{kg}$ CDDP and $1000 \mathrm{~Bq} / \mathrm{m}^{3}$ radon inhalation, suggesting that the function of the antioxidant SOD was enhanced by the radon inhalation. This finding is in line with the results of our previous study demonstrating the change of SOD activity in the kidneys of BALB/c mice (Kataoka et al., 2011). Therefore, SOD activity may contribute to the mitigation of $15 \mathrm{mg} / \mathrm{kg}$ CDDP-induced renal injury conferred by $1000 \mathrm{~Bq} / \mathrm{m}^{3}$ radon inhalation. Furthermore, according to the analysis of antioxidant activity in paratuberculosis positive cattle, there were no variation of SOD and GSH-PX activities in their sera. Since radon inhalation enhances the antioxidative function, the elevation of antioxidant activity for the biological defense system against the infection might be observed in these cattle after radon exposure (Cenesiz et al., 2016).

Although we used healthy mice for evaluating the effects of radon inhalation against the CDDP induced renal damage model in this study, the further study are needed to assess the effects of radon inhalation with the combination of various CDDP dose and radon concentration in the cancer mouse model.

\section{CONCLUSION}

In conclusion, evaluation of the differences in clinical signs, indexes of renal injury, and antioxidant activities suggests strain-specific effects of radon inhalation on CDDP-induced renal damage, with clear differences detected between $\mathrm{C} 57 \mathrm{BL} / 6 \mathrm{~J}$ and $\mathrm{BALB} / \mathrm{c}$ mice. These differences are assumed to result from intrinsic variations in the radiosensitivities of these strains. C57BL/6J mice have relatively low radiosensitivity characteristics, indicating that the effects of radon inhalation on CDDP-induced renal damage would be minimal, whereas $\mathrm{BALB} / \mathrm{c}$ mice have relatively high radiosensitivity, and exhibited high sensitivity to radon inhalation, which may be associated with radiation-induced DNA damage to further exacerbate the CDDP-induced renal damage. Moreover, comparison of the CDDP administration dose in BALB/c mice suggested that the combination of $15 \mathrm{mg} / \mathrm{kg}$ CDDP and $1000 \mathrm{~Bq} / \mathrm{m}^{3}$ radon inhalation is likely to protect against $\mathrm{CDDP}$-induced renal damage to some extent via increasing the SOD content. Based on these results, radon inhalation appears to be a suitable candidate for further studies of mitigating CDDP-induced renal injury in veterinary practice.

\section{ACKNOWLEDGMENTS}

The authors thank the staff of the Departments of Animal Resources and Radiation Research, Shikata Laboratory, Advanced Science Research Center, Okayama University for their technical support in this work.

Statement of conflict of interest

Authors have declared no conflict of interest.

\section{REFERENCES}

Aebi, H, Wyss, S.R., Scherz, B., and Gross, J., 1976. Properties of erythrocyte catalase from homozygotes and heterozygotes for Swiss-type acatalasemia. Biochem. Genet., 14: 791-807. https://doi.org/10.1007/BF00485342

Baehner, R.L., Murrmann, S.K., Davis, J. and Johnston, R.B. Jr., 1975. The role of superoxide anion and hydrogen peroxide in phagocytosis-associated oxidative metabolic reactions. J. clin. Invest.; 56: 571-576. https://doi.org/10.1172/JCI108126

Bradford, M.M., 1976. A rapid and sensitive method for the quantitation of microgram quantities of protein utilizing the principle of protein-dye binding. Analyt. Biochem., 72: 248-254. https://doi. org/10.1016/0003-2697(76)90527-3

Canon, M., 2016. Diagnosis and investigation of chronic kidney disease in cats. In Practice, 38: 2-9. https:// doi.org/10.1136/inp.i4914

Cenesiz, M., Ciftci, G., Dalgin, D., Kilic, Y., Yarim, F.G. and Cenesiz, S., 2016. Evaluation of oxidant and antioxidant capacity in paratuberculosis positive 
cattle. Pakistan J Zool., 48: 1603-1606.

ৎetin, R., Devirm, E., Klil ऽoglu, B., Avci, A., ৎandir, Ö. and Durak, L., 2006. Cisplatin impairs antioxidant system and causes oxidation in rat kidney tissues: possible protective roles of natural antioxidant foods. J. appl. Toxicol., 26: 42-46. https://doi. org/10.1002/jat.1103

Ecelbarger, A.C., Sands, M.J., Doran, J.J., Cacini, W. and Kishore, K.B., 2001. Expression of salt and urea transporters in rat kidney during cisplatininduced polyuria. Kidney Int., 60: 2274-2282. https://doi.org/10.1046/j.1523-1755.2001.00048.x

Finch, N.C., Syme, H.M. and Elliott, J., 2016. Risk factors for development of chronic kidney disease in cats. J. Vet. Intern. Med., 30: 602-610. https:// doi.org/10.1111/jvim.13917

Fiocchi, E.H., Cowgill, L.D., Brown, D.C., Markovich, J.E., Tucker, S., Labato, M.A. and Callan, M.B., 2017. The use of Darbepoetin to stimulate erythtopoiesis in the Treatment of anemia of chronic kidney diseases in dogs. J. Vet. Intern. Med., 31: 476-485. https://doi.org/10.1111/jvim.14681

Freeman, L., Becvarova, I., Cave, N., MacKay, C., Nguyen, P., Rama, B., Takashima, G., Tiffin, R., Tsjimoto, H. and Beukelen, V.P., 2011. Nutritional assessment guidelines. J. Small Anim. Pract., 52: 385-396. https://doi.org/10.1111/j.17485827.2011.01079.x

Galle, J., 2001. Oxidative stress in chronic renal failure. Nephrol. Dial. Transplant., 16: 2135-2137. https:// doi.org/10.1093/ndt/16.11.2135

Hanigan, H.M. and Devarajan, P., 2003. Cisplatin nephrotoxicity: Molecular mechanisms. Cancer Ther, 1: 47-61.

Hato, V.S., Khong, A., de Vries, M.J.I. and Lesterhuis, J.W., 2014. Molecular pathways: The immunogenic effects of platinum based chemotherapeutics. Clin. Cancer Res., 20: 2831-2837. https://doi. org/10.1158/1078-0432.CCR-13-3141

Kataoka, T., Nishiyama, Y., Toyota, T., Yoshimoto, M., Sakoda, A., Ishimori, Y., Aoyama, Y., Taguchi, T. and Yamaoka, K., 2011. Radon inhalation protects mice from carbon-tetrachloride-induced hepatic and renal damage. Inflammation, 34: 559-567. https://doi.org/10.1007/s10753-010-9263-7

Kataoka, T., Sakoda, A., Ishimori, Y., Toyota, T., Nishiyama, Y., Tanaka, H., Mitsunobu, F. and Yamaoka, K., 2011. Study of the response of superoxide dismutase in mouse organs to radon using a new large-scale facility for exposing small animals to radon. J. Radiat. Res., 52: 775-781. https://doi.org/10.1269/jrr.10072

Kataoka, T., Teraoka, J., Sakoda, A., Nishiyama, Y.,
Yamato, K., Moden, M., Ishimori. Y., Nomura, T., Taguchi, T. and Yamaoka, K., 2012. Protective effects of radon inhalation on carrageenan-induced inflammatory paw edema in mice. Inflammation, 35: 713-722. https://doi.org/10.1007/s10753-0119364-y

Kataoka, T., Tokunaga, R., Sakoda, A., Kawabe, A., Hanamoto, K. and Yamaoka, K., 2012. Basic study on positive effects of radon inhalation on pet's health. Radioisotopes, 61:1-8. https://doi. org/10.3769/radioisotopes.61.1

Kataoka, T., Kanzaki, N., Sasaoka, K. and Yamaoka, K., 2016. Mitigating effects of radon inhalation on neuropathic pain in mice and its possible application in veterinary care. In: Neuropathic pain, $1^{\text {st }}$ ed. Avid Science, Germany, pp. 1-16. http://www. avidscience.com/book/neuropathic-pain/

Kawai, Y., Nakao, T., Kurimura, N., Kohada, Y. and Gemba, M., 2006. Relationship of intracellular calcium and oxygen radicals to cisplatin-related renal cell injury. J. pharmacol. Sci., 100: 65-72. https://doi.org/10.1254/jphs.FP0050661

Knapp, W.D., Richardson, C.R., De Nicola, B.D., Long, G.G. and Blevins, E.W., 1987. Cisplatin toxicity in cats. J. Vet. Intern. Med., 1: 29-35. https://doi. org/10.1111/j.1939-1676.1987.tb01983.x

Knapp, W.D., Richardson, C.R., Bonney, L.P. and Hahn, K., 1988. Cisplatin therapy in 41 dogs with malignant tumors. J. Vet. Intern. Med., 2: 41-46. https://doi.org/10.1111/j.1939-1676.1988. tb01976.x

Kruidering, M., Van de Water, B., De Heer, E., Mulder, J.G. and Nagelkerke, F.J., 1997. Cisplatin-induced nephrotoxicity in porcine proximal tubular cells: Mitochondrial dysfunction by inhibition of complexes I to IV of the respiratory chain. $J$. Pharmacol. Exp. Ther., 280: 638-649.

Maliakel M.D., Kagiya, V.T. and Nair K.K.C., 2008. Prevention of cisplatin-induced nephrotoxicity by glucosides of ascorbic acid and $\alpha$-tocopherol. Exp. Toxicol. Pathol., 60: 521-527. https://doi. org/10.1016/j.etp.2008.04.015

Miyagawa, N., Arisato, M., Muratani, S., Sugano, Y., Oowaki, M. and Arai, N., 2013. Clinical study of $\beta$-glucan supplement to Demodex canis. $S A$ Dermatology, 9: 81-84.

Nakahara, S., Yoshino, K., Fujii, T., Uemura, H., Suzuki, M., Nishiyama, K. and Inohara, H., 2012. Nutritional surveillance in head and neck cancer patients during radiotherapy-the difference between concurrent chemoradiotherapy using high-dose cisplatin and radiotherapy alone. Nippon Jibiinkoka Gakkai Kaiho, 115: 902-909. https://doi. 
org/10.3950/jibiinkoka.115.902

Nematbakhsh, M., Ashrafi, F., Nasri, H., Talebi, A., Pezeshiki, Z., Eshraghi, F. and Haghighi, M., 2013. A model for prediction of cisplatin induced nephrotoxicity by kidney weight in experimental rats. J. Res. Med. Sci., 18: 370-373.

Nishiyama, Y., Kataoka, T. and Yamaoka, K., 2013. Study on Health effects of exposure to radon. Recent studies on effects and mechanisms of radon therapy. Trans. Atom. Energ. Soc. Jpn., 12: $267-$ 276.

Nishiyama, Y., Kataoka, T., Yamato, K., Etani, R., Taguchi, T. and Yamaoka, K., 2015. Radon inhalation suppresses nephropathy in streptozotocin-induced type-1 diabetic mice. J. Nucl. Sci. Technol., 53: 909-915. https://doi.org/10.1080/00223131.2015.1 078751

Noori, S. and Mahboob, T., 2010. Antioxidant effect of carnosine pretreatment on cisplatin -induced renal oxidative stress in rats. Indian J. clin. Biochem., 25: 86-91. https://doi.org/10.1007/s12291-010-0018-X

Oh, G.S., Kim, J.H., Shen, A., Lee, S.B., Yang, S.H., Shim, H., Cho, E.Y., Kwon, K.B., Kwak, T.H. and So, H.S., 2016. New Therapeutic concept of NAD redox balance for cisplatin nephrotoxicity. BioMed Res. Int., 2016: Article ID 4048390. https://doi. org/10.1155/2016/4048390

Onoue, M., 1960. Studies on the radiosensitivities of four in bred strains of mice. Nihon Igaku Housyasen Gakkai Zassi, 19: 2366-2379.

Ozkok, A. and Edelstein, L.C., 2014. Pathophysiology of cisplatin-induced acute kidney injury. BioMed Res. Int., 2014: Article ID 967826. https://doi. org/10.1155/2014/967826

Pabla, N. and Dong, Z., 2008. Cisplatin nephrotoxicity: Mechanisms and renoprotective strategies. Kidney Int., 73: 994-1007. https://doi.org/10.1038/ sj.ki.5002786

Palipoch, S. and Punsawasd, C., 2013. Biochemical and histological study of rat liver and kidney injury induced by cisplatin. J. Toxicol. Pathol., 26: 293299. https://doi.org/10.1293/tox.26.293

Parker, G.H., 2012. Genomic analyses of modern dog breeds. Mammal. Genom., 23: 19-27. https://doi. org/10.1007/s00335-011-9387-6

Prabhu, V.V., Kannan, N. and Guruvayoorappan, C., 2013. 1.2-Diazole prevents cisplatin-induced nephrotoxicity in experimental rats. Pharmacol. Rep., 65: 980-990. https://doi.org/10.1016/S17341140(13)71079-X

Rana, A.M., Khan, A.R., Nasiruddin, M. and Khan, A.A., 2016. Amelioration of cisplatin-induced nephrotoxicity by ethanolic extract of Bauhinia purpurea: An in vivo study in rats. Saudi J. Kidney Dis. Transpl., 27: 41-48. https://doi. org/10.4103/1319-2442.174068

Santos, N.A.G., Catăo, C.S., Martins, N.M., Curti, C., Bianchi, M.L.P. and Santos, A.C., 2007. Cisplatininduced nephrotoxicity is associated with oxidative stress, redox status unbalance, impairment of energetic metabolism and apoptosis in rat kidney mitochondria. Arch. Toxicol., 81: 495-504. https:// doi.org/10.1007/s00204-006-0173-2

Sasaoka, K., Kataoka, T., Kanzaki, N. and Yamaoka, K., 2016. Possible applications of radon therapy in veterinary care for oxidative stress-induced kidney damage. In: Free radicals and health (ed. R. Marianne), $1^{\text {st }}$ ed. Nova Science Publishers, USA, pp. 98-111. https://www.novapublishers. com/catalog/product_info.php?products_id=59870

Sung, J.M., Kim, H.D., Jung, J.Y., Kang, P.K., Lee S.A., Kim, W., Davaatseren, M., Hwang, T.J., Kim, J.H., Kim, S. M., Kwon, Y.D., and Park, K.S., 2008. Genistein protects the kidney from cisplatininduced injury. Kidney Int., 74: 1538-1547. https:// doi.org/10.1038/ki.2008.409

Tokunaga, J., Kobayashi, M., Kitagawa, A., Nakamura, C., Arimori, K. and Masahiro, N., 1996. Protective effects of N-Benzoyl amino acids on cisplatin nephrotoxicity in rats. Biol. Pharm. Bull., 19: 14511456. https://doi.org/10.1248/bpb.19.1451

Uehara, T., Yamate, J., Torii, M. and Maruyama, T., 2011. Comparative nephrotoxicity of cisplatin and nedaplatin: Mechanisms and histopathological characteristics. J. Toxicol. Pathol., 24: 87-94. https://doi.org/10.1293/tox.24.87

Ueki, M., Ueno, M., Morishita, J. and Maekawa, N., 2013. D-ribose ameliorates cisplatin-induced nephrotoxicity by inhibiting renal inflammation in mice. Tohoku J. Exp. Med., 229: 195-201. https:// doi.org/10.1620/tjem.229.195

Vapalahti, K., Virtala, A.M., Joensuu, A.T., Tiira, K., Tähtinen, J. and Lohi, H., 2016. Health and behaviroal survey of over 8000 finnish cats. Front. Vet. Sci., 3: 1-16. https://doi.org/10.3389/ fvets.2016.00070

Yamato, K., Kataoka, T., Nishiyama, Y. and Yamaoka, K., 2013. Recent studies on antinociceptive effects of radon therapy for pain-related diseases. Rad. Biol. Res. Commun., 48: 66-81.

Yao, X., Panichpisal, K., Kurtzman, N. and Nugent, K., 2007. Cisplatin nephrotoxicity: A review. Am. J. Med. Sci., 334: 115-124. https://doi.org/10.1097/ MAJ.0b013e31812dfe1e 